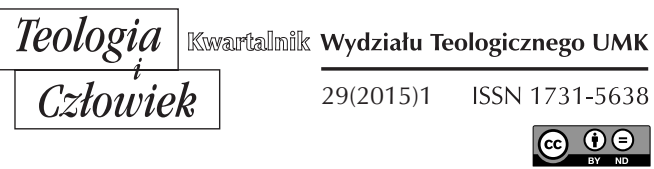

DAMIAN DOROCKI*

TORUŃ

\title{
JAKUB ARMINIUSZ - REFORMATOR TEOLOGII REFORMOWANEJ
}

DOI: http://dx.doi.org/10.12775/TiCz.2015.007

Postać Jakuba Arminiusza (1559-1609) na stałe wpisała się w historię teologii chrześcijańskiej. Jego myśl była bowiem przyczyną teologicznego sporu, jaki toczył się w Holandii na przełomie XVI i XVII w. wśród reformowanych protestantów. Te dwa fakty zaowocowały nurtem teologicznym, do dzisiaj zwanym arminianizmem, oraz tzw. Synodem w Dordrechcie (1618-1619), który sztywno zdefiniował teologię reformowaną. Leideński profesor dotknął tak istotnych zagadnień, że w konsekwencji jego nauka pobudziła do dyskusji cały kalwiński świat, który po jego śmierci potępił ją. Temat kontrowersji arminiańskiej jest kwestią obszerną, dlatego cała uwaga $\mathrm{w}$ tym artykule zostanie skupiona na tym, co działo się za życia Arminiusza, z pominięciem sprawy jej pośmiertnych losów.

Niniejsze opracowanie przybliży więc sylwetkę holenderskiego reformatora, jak i główne elementy jego nauczania, krytykujące ówczesną

* Damian Dorocki jest studentem IV roku teologii na Wydziale Teologicznym UMK w Toruniu. 
kalwińską teologię. W tym celu - dla lepszego zrozumienia problemu - zostanie zbadany kontekst historyczno-teologiczny, w jakim żył i tworzył Arminiusz. To pozwoli na dokonanie uczciwej ekspozycji i krytyki arminianizmu - reformowanego systemu teologicznego, głoszącego powszechną wolę zbawczą Boga.

\section{KIM BYŁ JAKUB ARMINIUSZ?}

Jacobus Arminius ${ }^{1}$ urodził się w $1559 \mathrm{r}^{2}{ }^{2} \mathrm{w}$ holenderskim miasteczku Oudewater. Reformatorowi przyszło wychowywać się bez ojca, który niestety zmarł przed jego narodzinami. Osieroconego Jakuba wziął pod opiekę Teodor Aemilius, miejscowy duchowny, który prawdopodobnie był krewnym Arminiusza. Aemilius, gdy tylko to było możliwe, wysłał młodego podopiecznego do Utrechtu, by tam pobierał pierwsze nauki. Po śmierci swego opiekuna w 1575 r. Arminiusz znalazł się pod mecenatem kolejnego członka rodziny, Rudolfa Snelliusa, uczonego z uniwersytetu w Marburgu, który będąc w Utrechcie, dojrzał drzemiący w nastoletnim uczniu potencjał i zabrał go ze sobą do Niemiec. W czasie studiów w Marburgu doszła Arminiusza smutna wiadomość o hiszpańskim najeździe na Oudewater. Wybrał się więc do rodzinnego miasta w poszukiwaniu krewnych. Niestety bliscy Jakuba, w tym jego matka, zginęli z rąk żołnierzy. Załamany wrócił do Marburga, by dokończyć naukę. Po roku postanowił jednak udać się do ojczyzny i w październiku 1576 r. został przyjęty na studia $\mathrm{w}$ uniwersytecie $\mathrm{w}$ Leiden. Była to wówczas młoda protestancka uczelnia, która konkurowała ze starszym katolickim uniwersytetem w Leuven. W Leiden reformator studiował teologię pod kierunkiem Guilhelmusa Feuguereusa i Lamberta Daneausa, kończąc naukę w 1581 r. Młody teolog zdecydował się po raz kolejny opuścić Niderlandy, by zostać studentem najbardziej prestiżowej kalwińskiej uczelni - Akademii

1 Właść. Jakob Harmenszoon. Jacobus Arminius to zlatynizowana wersja imienia i nazwiska.

2 Przez długi czas jako datę narodzin Arminiusza podawano rok 1560, jednak dzięki badaniom Carla Bangsa wiemy, że bardziej prawdopodobnym rokiem jego narodzin jest 1559. Por. C. Bangs, Arminius. A Study in the Dutch Reformation, Eugene 1998, s. 26. 
Genewskiej. Tam pogłębił znajomość teologii reformowanej, ucząc się pod okiem Teodora Bezy ${ }^{3}$ (1519-1605). W czasie nauki w Genewie reformator z Oudewater wdał się w dotyczący logiki spór i wyjechał na około dwa lata do Bazylei (1582-1584), po czym kontynuował studia w Akademii. W 1587 r. Arminiusz wrócił do Holandii, by rok później zostać ordynowanym na pastora w Amsterdamie. 16 sierpnia 1590 r. ożenił się z Lijsbet Reael, córką wpływowego Holendra Laurensa Reaela. W tym czasie głosił kazania na temat Listu św. Pawła do Rzymian i rozumiał kluczowe jego fragmenty inaczej $(\mathrm{Rz} 7 ; 9)$ niż ówcześni teolodzy reformowani. Zaczął też kwestionować naukę o podwójnej predestynacji, która utrzymywała, że Bóg w swej suwerenności przeznacza ludzi bezwarunkowo do zbawienia i potępienia. Już wtedy jego przeciwnicy oskarżyli go o herezję, jednak Arminiusz został oczyszczony z zarzutów przez władze Amsterdamu. Bronił się przede wszystkim tym, że Holenderski Kościół Reformowany nigdy nie przyjął jednego systemu teologicznego i zawsze dopuszczał różnicę zdań w kwestiach szczegółowych. To nie przerwało działań jego adwersarzy, którzy pragnęli oficjalnego uznania go za heretyka. Po pierwszych sporach reformator prowadził spokojne życie, aż do czasu gdy przyjął ofertę pracy w charakterze nauczyciela akademickiego. W 1603 r. Arminiusz otrzymał tytuł doktora teologii i został profesorem Uniwersytetu w Leiden, a dwa lata później nawet rektorem tej uczelni (1605-1606). Spotkał tam dozgonnego wroga w osobie Franciszka Gomarusa. Nie był to zresztą jedyny oponent leideńskiego profesora, choć z pewnością największy. Wiele zarzutów Gomarusa względem Arminiusza było nieprawdziwych i miało charakter polityczny. Oskarżał go np. o sprzyjanie katolickiej Hiszpanii i jezuitom, tylko dlatego że jego soteriologia nie była klasycznie monergistyczna, tak jak ortodoksyjna kalwińska nauka o zbawieniu. Te specyficzne pomówienia miały związek z dość krótką niepodległością Holandii, która była ówcześnie jeszcze młodym autonomicznym krajem, wyzwolonym spod jarzma hiszpańskiego. W tamtym czasie każdy, kto głosiłby poglądy takie jak Arminiusz, byłby oskarżony

${ }^{3}$ Beza był wybitnym uczonym protestanckim. Zasłużył się szczególnie tym, że usystematyzował teologię Jana Kalwina i wyostrzył doktrynę o predestynacji. Por. R.E. Olson, Historia teologii chrześcijańskiej. Dwadzieścia wieków tradycji i reform, tłum. K. Wiazowski, Warszawa 2003, s. 489-492; tenże, Against Calvinism, Grand Rapids 2011, s. 56. 
o katolicyzm i zdradę stanu. Holenderski reformator musiał zatem publicznie przedstawić i wyjaśnić swoje teologiczne stanowisko. Początkowo odbywało się to za murami uczelni (w latach 1604-1609). W $1608 \mathrm{r}$. profesor z Leiden napisał swe słynne Declaratio Sententiae, wysyłając to dzieło do władz holenderskich w Hadze. W sierpniu 1609 r. poproszono go o przyjazd. Pobyt Arminiusza w Hadze nie był długi. Przyczyną tego była gruźlica, która znacznie go osłabiła. Po powrocie do Leiden zmarł w październiku tego samego roku4. Na pogrzebie jeden z jego przyjaciół Piotr Bertius powiedział: „Był w Holandii człowiek: ci, co go znali, nie potrafili go odpowiednio ocenić, ci, którzy nie potrafili go ocenić, nigdy go odpowiednio nie znali”s.

\section{ARMINIUSZ I KALWINIZM}

\subsection{POCZĄTKI KONTROWERSJI}

Pierwszy teologiczny konflikt wywołany przez Arminiusza miał związek z jego kazaniami z lat 1591-1593 dotyczącymi Listu św. Pawła do Rzymian. Chodzi konkretnie o rozdziały 7. i 9. tego Listu. W przypadku pierwszego fragmentu sprawa dotyczyła ego z wierszy 14-25. Protestanci w ślad za św. Augustynem utożsamiali człowieka z Rz 7 z nawróconą osobą, która wciąż zmaga się z grzechem. Leideński teolog twierdził zaś, że kondycja moralna przedstawiona w tym fragmencie Biblii dotyczy nieodrodzonego człowieka. Gdyby nawrócona osoba wciąż miała taki problem z grzechem, znaczyłoby to, że łaska Boża nie ma mocy przemienienia grzesznika. Natomiast Reformator mocno podkreślał siłę Bożej łaski, która uświęca wierzącego. Jednakże trzeba pamiętać, że profesor z Leiden spotkał się z tego powodu z ostrą krytyką ${ }^{6}$. W czasie jego naukowej pracy

${ }^{4}$ Por. C. Bangs, dz. cyt., s. 25-55, 64-206, 231-331.

5 „In Holland there was a man: those who knew him could not adequately esteem him; those who did not esteem him, never adequately knew him", cyt. za: K.D. Stanglin, Th.H. McCall, Jacob Arminius. Theologian of Grace, New York 2012, s. 25.

${ }^{6}$ Por. C. Bangs, dz. cyt., s. 140, 186-192; A. Goudrian, "Augustine Asleep" or "Augustine Awake"? Jacobus Arminius's Reception of Augustine, w: Arminius, Arminianism and Europe: Jacobus Arminius (1559/60-1609), red. Th.M. van Leeuwen, K.D. Stanglin, 
na uniwersytecie (1603-1609) ten temat był jednym z kluczowych w dyskusji między nim a jego adwersarzami. Teologiczni oponenci Arminiusza z uwagi na swą pesymistyczną antropologię twierdzili, że nienawrócony człowiek nie może się zmagać z grzechem, będąc całkowicie jemu zaprzedanym. Leideńczyk odpowiadał, że Pismo mówi o dwóch typach zmagania człowieka ze złem moralnym (duplex lucta). Pierwsze toczy się między ciałem a umysłem, i to właśnie opisuje Rz 7,14-25. Drugie zaś dotyczy walki ciała i Ducha. Różnicę między tymi dwoma rodzajami starć można ujrzeć w ich konsekwencjach. W przypadku kontrowersji między ciałem a umysłem zazwyczaj wygrywa ciało. Kiedy natomiast Duch zmaga się z naszym grzechem, to On najczęściej zwycięża. Oczywiście Arminiusz nie chciał przez to zaprzeczyć totalnej deprawacji natury ludzkiej, gdyż poważnie traktował sprawę skutków upadku Adama i Ewy. Chciał on jedynie powtórzyć Pawłową myśl z Rz 6,14: „Albowiem grzech nie powinien nad wami panować, skoro nie jesteście poddani Prawu, lecz łasce”. Natomiast Rz 7,14 mówi o byciu „zaprzedanym w niewolę grzechu”. Taka sytuacja dotyczy poddanych Prawu nieodrodzonych ludzi ${ }^{7}$.

W przypadku Rz 9 holenderski reformator swoją interpretacją tego tekstu zaprzeczał bezwarunkowej podwójnej predestynacji. Na początku unikał tematu predestynacji, gdy przyszło mu się tłumaczyć ze swoich przekonań przed konsystorzem kościoła w Amsterdamie, jednak w późniejszym czasie wyjaśnił swoje stanowisko pisemnie ${ }^{8}$. Mianowicie w Rz 9 jest mowa o Bożym wybraniu. Kalwińscy teolodzy rozumieli to jako wybór indywidualnych osób. Innymi słowy Bóg postanowił o losie każdej pojedynczej osoby. Arminiusz pojmował to w sposób bardziej ogólny. Ezaw i Jakub pojawiający się tam to figury nie osób, a grup osób. Ezaw reprezentuje szukających usprawiedliwienia z uczynków Prawa, Jakub zaś szukających sprawiedliwości płynącej z wiary w Chrystusa. Leideński profesor odnosił Boże bezwarunkowe wybranie do zbiorów wierzących i niewierzących. Podstawą wybrania partykularnego była bo-

M. Tolsma, Leiden-Boston 2009, s. 55; R.E. Picirilli, Grace, Faith, Free Will. Contrasting Views of Salvation. Calvinism and Arminianism, Nashville 2002, s. 6-7; K.D. Stanglin, Arminius on the Assurance of Salvation. The Context, Roots and Shape of the Leiden Debate, 1603-1609, Leiden-Boston 2007, s. 124-125; K.D. Stanglin, Th.H. McCall, dz. cyt., s. 29.

7 Por. K.D. Stanglin, dz. cyt., s. 125.

8 Por. C. Bangs, dz. cyt., s. 128. 
ska wszechwiedza o wierze (praescientia) $(\mathrm{Rz} 8,29)$. Stwórca przewidział wolny wybór każdego człowieka i na tej podstawie przeznaczał do nieba lub piekła (warunkowa predestynacja) ${ }^{9}$. Kalwińscy adwersarze Arminiusza szybko dostrzegli w jego nauczaniu elementy synergizmu, co skłoniło ich do mocnego odzewu ${ }^{10}$.

\subsection{BOŻA SUWERENNOŚĆ W MYŚLI ARMINIUSZA}

„Owszem, Bóg może uczynić to, co chce ze swą własnością; jednak nie może niesłusznie postąpić z tym, co do Niego należy, jego wola jest ograniczona $\mathrm{w}$ ramach sprawiedliwości" ${ }^{11}$. Jak widać po zacytowanych słowach, swoją interpretacją tego tekstu Arminiusz nie absolutyzował woli Stwórcy. Zawsze patrzył na nią w perspektywie Bożej natury, która jest miłosierna i sprawiedliwa. Wierzył on zatem w „ograniczenie” Boga spowodowane jego niezmiennym charakterem ${ }^{12}$. Sprawiedliwość wyprzedza wolność, dlatego też iustitia Dei jest normą dla voluntas Dei. Niepodobna, by Stwórca mógł chcieć czegoś niesprawiedliwego, to kłóci się z jego naturą ${ }^{13}$. Było to $\mathrm{w}$ świecie reformowanym zupełnie inne spojrzenie na tę kwestię. Reformator z Oudewater nie uległ woluntarystycznym tendencjom ze względu na swój metafizyczny realizm. Twierdził, że Bóg jest dobry w sposób konieczny, gdyż taką ma naturę. Nominalistyczni oponenci Arminiusza utrzymywali, że Absolut nie jest dobry z powodu swojego stałego charakteru, ale dlatego, że tak wybrał (woluntaryzm) ${ }^{14}$.

Profesor z Leiden przyznawał, że nic nie dzieje się bez woli Bożej. Jednak w jego teologii nie implikowało to zdeterminowania przez

9 Por. R.E. Olson, Historia teologii, s. 495-496, 503; K.D. Stanglin, Th.H. McCall, dz. cyt., s. 132-134, 136.

10 Por. R.E. Olson, Historia teologii, s. 496.

11 "God can indeed do what He wills with His own; but He cannot will to do with His own what He cannot rightfully do, for His will is circumscribed within the bounds of justice". J. Arminius, Friendly Conference with Mr. Francis Junius, cyt. w: tenże, Arminian Theology. Myths and Realities, Downers Grove 2006, s. 119-120.

12 Por. tamże, s. 119.

13 Por. W. den Boer, Jacobus Arminius. Theologian of God's Twofold Love, w: Arminius, Arminianism, s. 35-36.

${ }^{14}$ Por. R.E. Olson, Arminian Theology, s. 103. 
Stwórcę wszystkich wydarzeń. Bóg wiele rzeczy dopuszcza i dlatego nic nie mogłoby się wydarzyć, jeśliby On na coś nie przyzwolił. Boża kontrola polega na ostatecznym wyprowadzeniu wszystkiego w stronę dobra. Stwórca natomiast nie jest przyczyną grzechu i zła. W tym przypadku Bóg jedynie zgodził się na ich zaistnienie, gdyż szanuje wolną wolę swoich stworzeń. Dlatego upadek Adama nie mógł Go zaskoczyć ze względu na Jego wszechwiedzę. Arminiusz wierzył również, że Bóg współdziała z człowiekiem w jego aktach. Bez swego Stworzyciela człowiek nie jest w stanie niczego uczynić. Można by pomyśleć, że Bóg jest odpowiedzialny za upadek pierwszych ludzi. Jednak Leideńczyk odpowiada, że Stwórca może być uznany za sprawcę jedynie aktu, nie grzechu, który tylko dopuszcza. Bóg godzi się na grzech człowieka i kooperuje z nim w działaniu, by utrzymać ludzką wolność. Tak więc to nie zło jest zgodne z Jego wolą, ale pozostawienie wolnego wyboru swemu stworzeniu. By to zrozumieć, trzeba wiedzieć, co Reformator powiedział o woli Boga. Dokonując sztucznego podziału na uprzednia i następująca wolę Stwórcy ${ }^{15}$, Arminiusz stwierdził, że Boży dopust upadku zanim się on jeszcze wydarzył, istniał w uprzedniej woli, współdziałanie zaś w akcie grzechu ma związek z następująca wolą i jest spowodowane wolnym wyborem człowieka (choć należy przyznać, że Bóg niechętnie kooperuje z ludźmi wybierającymi zło). Innymi słowy uprzednia wola jest wolą planującą i dopuszczającą pewne fakty, a następujaca konsekwentną w stosunku do tych faktów. Pierwszy rodzaj woli jest idealny, nikt nie może w niej grzeszyć. Dlatego Bóg, dopuszczając grzech, nie aprobuje go, przez co się sam ogranicza, gdyż po 1. szanuje wolność ludzką, i po 2. nie wymusza niczego na człowieku ${ }^{16}$. Nie znaczy to, że w Bogu jest jakaś sprzeczność lub zmienność. Arminiusz zgadzał się ze św. Tomaszem z Akwinu, że Bóg jest czystym aktem (Deus est actus purus). Ta pozorna potencjalność i podział w woli Stwórcy wynikały $\mathrm{z}$ relacji do stworzenia. To ludzie są zmienni, a nie Bóg, który zawsze miłuje sprawiedliwość i nienawidzi grzechu ${ }^{17}$.

15 Ang. antecedent will i consequent will. Nie jest to koncepcja oryginalnie arminiańska. W tym punkcie reformator podążał za myślą św. Jana Damasceńskiego. Por. K.D. Stanglin, Th.H. McCall, dz. cyt., przyp. 109, s. 71.

${ }_{16}$ Por. R.E. Olson, Arminian Theology, s. 120-123; K.D. Stanglin, Th.H. McCall, dz. cyt., s. 71-72.

17 Por. K.D. Stanglin, Th.H. McCall, dz. cyt., s. 74, 75. 


\subsection{ANTROPOLOGIA}

Jeśli chodzi o antropologię teologa z Leiden, to należy wspomnieć o tym, że uważał on, iż obraz Boży w człowieku składał się z dwóch części przed upadkiem - naturalnej i nadnaturalnej. Naturalne podobieństwo mieści w sobie rozumność, wolność i uczucia, nadnaturalne zaś wiedzę o rzeczach niebieskich i sprawiedliwość. Oba te obrazy zawierają w sobie obraz Boży i przejawiają się szczególnie w ludzkiej duszy ${ }^{18}$. Przez wolny akt Adam zgrzeszył i ściągnął na siebie winę oraz karę. Upadek spowodował utratę nadnaturalnego obrazu Bożego, tj. wiedzy o sprawach Bożych i „genezyjskiej” prawości, którą była obecność Ducha Świętego. „Odebranie pierwotnej sprawiedliwości i świętości, które były efektem przebywania Ducha Świętego w człowieku [...]"19 sprawiło, że istota ludzka stała się śmiertelna. Grzech Adama wpłynął na całą rasę ludzką, powodując jej znalezienie się pod panowaniem śmierci. Grzech pierworodny doprowadził do „uwięzienia” woli. Owo zniewolenie sprawia, że człowiek zwraca się ku złu i szuka jedynie tego, co ziemskie. Rozum i wola już nie są w stanie zmierzać w stronę dobra, ponieważ te dwie władze duszy są pogrążone w ciemności i grzechu ${ }^{20}$. Arminiusz nie mógł bardziej dobitnie przedstawić swego poglądu w tej kwestii niż w poniższej wypowiedzi:

„W tym stanie [tzn. upadłym], wolna wola człowieka w stosunku do prawdziwego dobra nie jest jedynie poraniona, okaleczona, niestabilna, wykrzywiona i wątła, ale jest również uwięziona, zniszczona i zgubiona.

${ }_{18}$ Por. J.M. Hicks, The Theology of Grace in the Thought of Jacobus Arminius and Philip van Limborch. A Study in the Development of Seventeenth Century Dutch Arminianism, (dysertacja doktorska) Westminsterskie Seminarium Teologiczne 1985, s. 18-19; K.D. Stanglin, Th.H. McCall, dz. cyt., s. 148.

19 „Withdrawal (privatio) of that primitive righteousness and holiness, which, because they are the effects of the Holy Spirit dwelling in man", J. Arminius, Public Disputations, w: Works of James Arminius, tłum. J. Nichols, W.R. Bagnall, Grand Rapids 1977, t. 1, s. 485, cyt. w: J.M. Hicks, dz. cyt., s. 20. Kilku autorów, za którymi cytuję Arminiusza, korzystało z różnych wydań zbioru jego dzieł, dlatego w niektórych przypisach do cytatów będzie podane, z którego roku pochodzi konkretna edycja Works of James Arminius.

${ }_{20}$ Por. J.M. Hicks, dz. cyt., s. 20-21; K. D. Stanglin, Th.H. McCall, dz. cyt., S. $150-151$. 
Jej siły są nie tylko osłabione i bezużyteczne - chyba że są wsparte łaską - ale [wola] także nie ma żadnej mocy, wyłączając te przypadki gdy jest poruszona Bożą łaską. Tak jak Chrystus powiedział: »Beze mnie nic uczynić nie możecie«"21.

Holenderski reformator w swej antropologii był jak najbardziej protestantem. Nauczał, że umysł jest pozbawiony zbawiennej wiedzy i zagubiony oraz że nie jest w stanie bez pomocy łaski poznać i zrozumieć Ewangelii, wola zaś nie miłuje tego, co prawdziwie dobre i zgodne z Bożą wolą, dlatego z konieczności kroczy ku złu. Wynikiem tego stanu rzeczy jest całkowita moralna i duchowa niemoc człowieka. Ludziom niezbędna jest spirytualna rezurekcja i odnowa, która jest dziełem Boga w Chrystusie przez Ducha Świętego. Jedynie odrodzony człowiek ma dobrze ukierunkowane władze duchowe. Nienawrócona osoba posiada wolną wolę tylko do czynienia grzechu ${ }^{22}$.

\subsection{SOTERIOLOGIA}

Prawdziwą „kością niezgody” między Arminiuszem a jego oponentami w kwestii zbawienia był temat łaski. Przez wzgląd na swoje miłosierdzie Bóg postanowił wybawić martwego duchowo człowieka, który sam nie potrafiłby tego zrobić. To implikuje konieczność łaski w dziele zbawienia. Jednak powstaje pytanie: czy łaska jest nieodparta? Zważywszy na fakt zniewolonej woli, kalwini twierdzili, że człowiek nie może się oprzeć łasce. Boże działanie na człowieka musi być „przymusowe”, gdyż istota ludzka nigdy by w sposób wolny nie wybrała Boga. Jednak leideński profesor uważał, że Stwórca zamiast niszczyć ludzką wolę, popycha ją w dobrym kierunku i utrzymywał, że łaska Boża może zostać

${ }_{21}$ "In this state, the free will of man towards the true good is not only wounded, maimed, infirm, bent, and weakened (attenuatum); but it is also imprisoned (captivatum), destroyed, and lost. And its powers are not only debilitated and useless unless they are assisted by grace, but it has no powers whatever except such as is excited by Divine grace. For Christ has said, 'Without me ye can do nothing"', J. Arminius, Public Disputations, w: Works, t. 1, s. 526, cyt. w: J.M. Hicks, dz. cyt., s. 21.

${ }^{22}$ Por. J.M. Hicks, dz. cyt., s. 22-23; R.E. Olson, Arminian Theology, s. 141-142; R.E. Picirilli, dz. cyt., s. 149-152. 
przez człowieka zaakceptowana lub odrzucona. Innymi słowy łaska jest odparta $^{23}$ (Gratia est non vis irresistibilis). Intencją reformatora nie było oczywiście osłabienie łaski w miejsce wzmocnienia ludzkiej woli, czego dowodem są jego słowa:

„Bożej łasce przypisuję początek, kontynuację i wypełnienie wszelkiego dobra, tak dalece, że odrodzona osoba bez tej uprzedzającej i pobudzającej, następującej i współpracującej łaski, nie może nawet myśleć, chcieć, czy czynić dobra, ani również odeprzeć jakiejkolwiek pokusy. Z tego wynika, że nie pomniejszam Bożej łaski, przypisując zbyt wiele [miejsca] ludzkiej wolnej woli”24.

Arminiusz w swej soteriologii nauczał o uniwersalnym odkupieniu. Dla niego Bóg nie odmawia nikomu swej łaski. Natomiast dwojakość reakcji ludzi na Ewangelię nie jest spowodowana Bożym postanowieniem, ale wolnym wyborem człowieka. Zbawiciel oferuje wszystkim wystarczającą do nawrócenia się łaskę, ale staje się ona skuteczna dopiero po jej przyjęciu $^{25}$. Ta uprzedzajaca łaska ${ }^{26}$ (gratia praeveniens) jest koniecznie potrzebna do tego, by grzesznik mógł uwierzyć i żałować swoich grze-

23 Por. W.S. Gunter, Arminius and his Declaration of Sentiments. An Annotated Translation with Introduction and Theological Commentary, Waco 2012, przyp. 100, s. 141; K.D. Stanglin, dz. cyt., s. 79-81.

24 "I ascribe to God's grace the origin, the continuance, and the fulfillment (het beghinsel, den voorgangh, ende de volbrenginghe) of all good, also so far that the regenerate person himself, without this prevenient and stimulating, following, and cooperating (medewerckende) grace, can neither think, will or do good, nor also resist any evil temptation. From this it appears that I do not diminish God's grace by attributing too much to humanity's free will (vryen wille)." J. Arminius, Declaration of Sentiments, w: Works, tłum. J. Nichols, W. Nichols, Grand Rapids 1986, t. 1, s. 664, cyt. w: K.D. Stanglin, dz. cyt., s. 80.

${ }^{25}$ Skuteczna do tego, by usprawiedliwić i uświęcić grzesznika. Arminiusz rozróżniał między wystarczalnością i skutecznością łaski. Najpierw uprzedzająca łaska umożliwia grzesznikowi nawrócenie, po pozytywnej odpowiedzi na nią łaska ta staje się skuteczna (gratia subsequens), gdyż realizuje to, co było potencjalne, zanim człowiek się nawrócił. Por. W.S. Gunter, dz. cyt., s. 184; J.M. Hicks, dz. cyt., s. 30-32; K.D Stanglin, Th.H. McCall, dz. cyt., s. 154.

${ }^{26} \mathrm{Na}$ temat gratia praeveniens więcej zob. R.E. Picirilli, dz. cyt., s. 153-159; K.D Stanglin, Th.H. McCall, dz. cyt., s. 151-157. 
chów ${ }^{27}$. W świetle arminiańskiej nauki o łasce wyprzedzającej nienawróconego grzesznika znika wszelki zarzut, iż holenderski reformator był zwolennikiem pelagianizmu, zakładającego naturalną zdolność człowieka do zainicjowania zbawienia. W rzeczywistości dla leideńczyka możliwość wolnego wyboru lub odrzucenia Bożej oferty wyzwolenia z grzechu mogła zaistnieć tylko dzięki uwalniającej umysł łasce. Dlatego można powiedzieć, że Arminiusz wierzył w wyzwoloną, zamiast wolną wolę. „Żaden człowiek nie wierzy w Chrystusa, poza tym, który został najpierw nakłoniony i przygotowany przez uprzedzającą łaskę" ${ }^{28}$. Łaska jest początkiem, środkiem i końcem duchowego życia człowieka. Przez gratia praeveniens należy rozumieć wpływ Ducha Świętego na serce nieodrodzonej osoby (J 16,8; Dz 16,14). Jego moc otwiera grzesznika na przyjęcie zbawienia przez skruchę i wiarę ${ }^{29}$. Wiara pozostaje zatem dla leideńskiego profesora darem, gdyż człowiek może ją posiadać wyłącznie dzięki Bożej łasce (Fides est opus et donum supernaturale non naturale). Reformator nie pozostawił $\mathrm{w}$ swej teologii zbawienia miejsca na ludzkie zasługi ${ }^{30}$.

Czy nauka o wymogu ludzkiej kooperacji czyni Arminiusza nadal monergistą? Czy może jego soteriologia miała charakter synergistyczny? Światowej sławy znawca myśli leideńczyka Carl Bangs uważał, że pozostał on monergistą, zważywszy na znaczenie i prymat łaski w soteriologii $\operatorname{arminiańskiej~}^{31}$. Z kolei Roger E. Olson arminiańską teologię zbawienia nazywa ewangelicznym synergizmem, ponieważ zakłada ona współpracę z Bogiem ze strony człowieka, jednak możliwość współdziałania nie jest

${ }^{27}$ Por. K.D. Stanglin, dz. cyt., s. 82-83; R.E. Olson, Arminian Theology, s. 20, $161-162$.

28 "No man believes in Christ except him who has been previously disposed and prepared by preventing or preceding grace". J. Arminius, Certain Articles to Be Diligently Examined and Weighed, w: Works, t. 2, tłum. J. Nichols, W. Nichols, Grand Rapids 1996, s. 724, cyt. w: R.E. Olson, Arminian Theology, s. 145.

${ }_{29}$ Ten rodzaj łaski ma cztery aspekty: wezwanie, przekonanie, oświecenie i uzdolnienie. Tamże, s. 160.

${ }^{30}$ Por. K.D. Stanglin, dz. cyt., s. 76-98; R.E. Olson, Historia teologii, s. 504-505; tenże, Arminian Theology, s. 35-37, 142-146; tenże, Arminianism is Evangelical Theology, „Wesleyan Theological Journal” 46 (2011) 2, s. 10-16; R.E. Picirilli, dz. cyt., s. $153-155$.

31 Por. C. Bangs, dz. cyt., s. 342-344. 
ludzką zasługą, lecz boską ${ }^{32}$. Należy wszakże uczciwie powiedzieć, że problem kategoryzacji soteriologii profesora $\mathrm{z}$ Leiden ma związek $\mathrm{z}$ tym, że zawiera ona $\mathrm{w}$ sobie elementy monergizmu i synergizmu ${ }^{33}$.

Powyższe nauczanie holenderskiego reformatora miało wpływ na jego porządek zbawienia (ordo salutis), który prezentował się następująco ${ }^{34}$ :

\section{Wezwanie $=$ gratia praeveniens}

2. Nawrócenie:

a. Żal za grzechy

b. Wiara

3. Usprawiedliwienie

4. Nowo narodzenie

5. Uświęcenie

To, co różniło Arminiusza od kalwińskich adwersarzy w tej sprawie, ma związek z umieszczeniem nowo narodzenia dopiero po nawróceniu. Teolodzy reformowani do dziś nauczają, że człowiek musi być najpierw odrodzony, by mógł pokutować i uwierzyć ${ }^{35}$.

W kwestii usprawiedliwienia profesor z Leiden był ortodoksyjnym protestantem, zgadzając się z Lutrem i Kalwinem, że można je osiągnąć jedynie z łaski przez wiarę (Ef 2,8-9) oraz że jego fundamentem jest sprawiedliwość Chrystusa ${ }^{36}$. Sam Arminiusz wyraził to w następujący sposób:

„Wierzę, że grzesznicy są uznani za sprawiedliwych wyłącznie ze względu na posłuszeństwo Chrystusa; i że sprawiedliwość Chrystusa jest jedyną materialną przyczyną, ze względu na którą Bóg przebacza grzechy wierzących i uznaje ich za sprawiedliwych, jak gdyby doskonale wypełnili Prawo. [...] Bóg ustanowił swego Syna Jezusa Chrystusa przebłaganiem, tronem łaski (lub miejscem miłosierdzia) przez wiarę w Jego krew" ${ }^{37}$.

32 Por. R.E. Olson, Historia teologii, s. 504-505; tenże, Arminian Theology, s. 165.

${ }_{33}$ Por. J.M. Hicks, dz. cyt., s. 35-36.

${ }_{34}$ Por. R.E. Picirilli, dz. cyt., s. 160.

35 Por. R.E. Olson, Against Calvinism, s. 50-52; R.E. Picirilli, dz. cyt., s. 142-145.

${ }^{36}$ Por. J.M. Hicks, dz. cyt., s. 43-49; R.E. Olson, Historia teologii, s. 499-500; tenże, Arminian Theology, s. 200-208; K.D. Stanglin, Th.H. McCall, dz. cyt., s. 165-169.

37 "I believe that sinners are accounted righteous solely by the obedience of Christ; and that the righteousness of Christ is the only meritorious cause on account of 


\subsection{KRYTYKA PREDESTYNACJI}

Sprawa krytyki predestynacji miała związek z dwiema postkalwińskimi szkołami, supralapsariańska i infralapsariańskga ${ }^{38}$. Z uwagi na swe odmienne zrozumienie kluczowych tekstów Listu do Rzymian, reformator musiał się wypowiedzieć w sprawie tych dwóch odmian predestynacjonizmu. Należy zaznaczyć, że sam profesor z Leiden wierzył w Bożą elekcję, jednak inaczej ją rozumiał.

Niezgoda Arminiusza na supralapsarianizm miała związek przede wszystkim z tym, że ta odmiana predestynacjonizmu w sposób szczególny przypisywała Bogu autorstwo grzechu ${ }^{39}$. Mianowicie, Bóg najpierw przeznaczył ludzi do zbawienia i potępienia, co implikuje upadek Adama i Ewy. Innymi słowy najpierw postanowił o ostatecznym losie każdego, a potem dopiero człowiek stał się wierzącym lub niewierzącym. Supralapsarianizm pomija zupełnie ludzką odpowiedzialność za decyzje i czyny. Bóg nie zbawia tych, którzy mu się dobrowolnie oddali, ale tych, których wybrał i przeznaczył do tego. Według holenderskiego reformatora to obraża Boga oraz nie jest zgodne z Jego naturą. Jedynym prawdziwym grzesznikiem jest Stwórca, bo to on zdeterminował powstanie grzechu. A przecież wszystko, czego Bóg chce i czyni, jest dobre. Dlatego grzech przestaje być grzechem, a Stwórca jest największym obłudnikiem, gdyż każe za grzech, którego jest twórcą ${ }^{40}$. Supralapsarianizm traktuje zatem ludzi jak abstrakcyjne podmioty, niemające jeszcze bytu, a już będące zbawionymi lub potępionymi ${ }^{41}$.

which God pardons the sins of believers [...] God hath set forth his Son Jesus Christ to be a propitiation, a throne of grace (or mercy-seat) through faith in his blood", J. Arminius, Declaration, w: Works, t. 1, s. 700, cyt. w: R.E. Olson, Arminian Theology, s. 203.

38 Supralapsarianizm utrzymuje, że Bóg postanowił zbawić i potępić wybranych ludzi jeszcze przed zadecydowaniem o ich stworzeniu i dopuszczeniem do upadku Adama i Ewy. Infralapsarianizm subordynował predestynację wyborowi stworzenia i przyzwoleniu na upadek pierwszych ludzi. Por. F. Leroy Forlines, Classical Arminianism. A Theology of Salvation, Nashville 2011, s. 36; R.E. Olson, Historia teologii, s. 490-492; R.E. Picirilli, dz. cyt., s. 10, 32-33.

39 Podobnych argumentów przeciw podwójnej predestynacji kilkadziesiąt lat wcześniej używał Filip Melanchton (1497-1560). Zob. R.M. Leszczyński, Ojcowie Reformacji i filozoficzne watki ich teologii, Warszawa 2010, s. 77-78.

${ }^{40}$ Por. R.E. Olson, Historia teologii, s. 501.

${ }^{41}$ Por. tenże, Arminian Theology, s 183. 
Mimo że infralapsarianizm w porządku Bożych postanowień przeznaczenie do zbawienia i zagłady ludzi subordynuje dekretom o stworzeniu i upadku, jest wciąż heretycki, ponieważ uznaje upadek ludzkości za nieodzowny, a sprawcą grzechu oczywiście jest Bóg ${ }^{42}$. Ponadto w opinii Arminiusza zwolennicy tego nurtu spychają Chrystusa na drugie miejsce względem podwójnej predestynacji, umniejszając rolę Syna Bożego, jaką odegrał w dziele zbawienia człowieka ${ }^{43}$.

Generalnie można powiedzieć, że leideńczyka przede wszystkim w podwójnej predestynacji nie zadowalał fakt wykluczenia pewnych osób z możliwości zbawienia oraz bezwarunkowe obdarzenie wiarą tylko wybranych jednostek, mimo że Bóg oferuje swój ratunek każdemu grzesznikowi ${ }^{44}$. Innymi słowy, w obydwu przypadkach Stwórca postępuje nielogicznie, jako że „swoje zaproszenie do wiary w Chrystusa kieruje On do tych [tzn. potępionych], którym nie przeznaczył Zbawiciela" ${ }^{45}$ (kalwińscy teolodzy, fakt głoszenia Ewangelii wszystkim istotom ludzkim tłumaczą tym, że Bóg nie objawił, którzy są jego wybranymi ${ }^{46}$, a poza tym nie należy ogólnego Bożego wezwania do pokuty i wiary traktować jako oferty ${ }^{47}$ ).

\subsection{ARMINIUSZA NAUKA O PREDESTYNACJI}

Jak było wspomniane wcześniej, Jakub Arminiusz wierzył w predestynację. Uważał ją za szczególną biblijną prawdę. Jednak inaczej rozumiał Boże wybranie niż jego przeciwnicy, tacy np. jak Franciszek Gomarus. Opierając się na Rz 8 i 9, odkrył, że Boża elekcja ma dwa oblicza - bezwarunkowe i warunkowe. Predestynacja generalna (dotycząca Kościoła i niewierzących) jest bezwarunkowa, ta zaś odnosząca się do poszczególnych jednostek warunkowa, mająca fundament w Bożej wszechwiedzy.

42 Por. tenże, Historia teologii, s. 501.

${ }^{43}$ Por. tenże, Arminian Theology, s. 183.

${ }^{44}$ Por. tamże, s. 181.

${ }^{45}$ J. Arminius, Examination of Dr. Perkin's Pamphlet on Predestination, w: Works, t. 3, s. 313. "...His exhortation to faith addressed to such [i.e. the reprobate], He requires them to believe in Christ, whom, however, He has not set forth as a Savior to them", cyt. w: tamże, s. 181.

${ }^{46}$ Por. tenże, Against Calvinism, s. 151.

${ }^{47}$ Por. tenże, Arminian Theology, s. 182. 
Arminiańskie cztery dekrety Boże $e^{48}$ pokazują, jak głęboko chrystocentryczna była nauka o Bożej elekcji teologa z Leiden. Brzmią one następująco:

1. „Pierwszym bezwarunkowym i absolutnym postanowieniem Bożym dotyczącym zbawienia grzesznego człowieka jest ustanowienie jego Syna Jezusa Chrystusa jako Pośrednika, Odkupiciela, Zbawiciela, Kapłana i Króla, który ma moc zniszczyć grzech swoją własną śmiercią, nabyć utracone zbawienie swoim posłuszeństwem oraz udzielić tego swoją mocą".

2. „Drugim ścisłym i absolutnym Bożym dekretem jest łaskawie przyjąć pokutujących oraz wierzących, i w Chrystusie oraz przez Niego dokonać zbawienia, tych którzy wytrwają; ale wszystkich niepokutujących i niewierzących pozostawić $\mathrm{w}$ grzechu i pod gniewem, oraz potępić ich jako obcych Chrystusowi”.

3. „Trzecim Bożym postanowieniem jest udzielenie w wystarczający i skuteczny sposób środków koniecznych do pokuty i wiary; taki porządek Bóg ustanowił w zgodzie ze swoją mądrością, przez którą wie, co jest właściwe dla jego miłosierdzia jak i srogości; oraz w zgodzie ze swą sprawiedliwością, przez którą jest gotów przyjąć to, cokolwiek jego mądrość może nakazać i zrealizować".

4. „Po tych dekretach następuje czwarte rozporządzenie, przez które Bóg postanawia zbawić i potępić pewne konkretne osoby. Ten dekret ma oparcie w Bożej wszechwiedzy, dzięki której Bóg wie od wieczności, kto - zgodnie z udzieleniem odpowiednich środków do skruchy i wiary - dzięki jego uprzedzającej łasce uwierzy, i dzięki późniejszej łasce wytrwa, oraz wie, kto nie uwierzy i nie wytrwa" ${ }^{\prime \prime}$.

48 Por. W. den Boer, art. cyt., w: Arminius, Arminianism, s. 48-49; W.S. Gunter, dz. cyt., s. 180; R.E. Olson, Historia teologii, s. 502; tenże, Arminian Theology, s. 183-184; R.E. Picirilli, dz. cyt., s. 50; K.D. Stanglin, dz. cyt., s. 86-87.

49 "The first precise and absolute (precijs ende absoluyt) decree of God, concerning the salvation of sinful men, is that he has decreed to appoint (stellen) his son Jesus Christ as a Mediator, Redeemer, Savior, Priest, and King, who might destroy sin through his death, obtain (verwerve) the lost salvation through his obedience, and communicate it through his power.

The second precise and absolute decree of God is that he has decreed to receive in grace those who repent and believe, and in Christ, for Christ's sake, and through Christ, to save those who persevere (volherdende); and to leave in sin and under wrath, and to damn, the impenitent and unbelieving as foreign from Christ. 
To, co musiało zdumieć ówczesnych Arminiuszowi teologów, to brak wymienienia wśród Bożych nieodmiennych dekretów postanowień o upadku i stworzeniu. Dla reformatora wielkim błędem było łączenie stworzenia $\mathrm{z}$ odkupieniem $\mathrm{w}$ tym sensie, że $\mathrm{z}$ tego pierwszego czyni się jedynie środek potrzebny do zaistnienia upadku i zbawienia grzesznego człowieka $^{50}$. Leideńczyk nie uważał, że upadek Adama i Ewy był Bożym zrządzeniem, tylko dopustem. Dlatego też Boże postanowienia o zbawieniu są logicznie wtórne względem przyzwolenia na pojawienie się grzechu wśród ludzi ${ }^{51}$. Predestynacja dotyczy tu przede wszystkim zbawienia $w$ i przez Chrystusa, ponieważ Syn Boży jest jedynym przeznaczonym ${ }^{52}$. Wynika to z tego, że dla Arminiusza Jezus Chrystus nie był li tylko wykonawcą nieodmiennego Bożego postanowienia, ale jego fundamentem. Dlatego wszystkie boskie dekrety wiążące się z odkupieniem mają swój początek w ustanowieniu Syna Bożego Zbawicielem. Innymi słowy, wszystkie pozostałe postanowienia wypływają z pierwszego, jakim jest przeznaczenie Chrystusa od wieczności do bycia Pośrednikiem i Odkupicielem $^{53}$. „Umieszczamy Chrystusa jako fundament tej predestynacji [...]. Przez miłość, którą Bóg kocha ludzi dla ich zbawienia, i zgodnie z którą zamierza dać im życie wieczne, którego nie ma poza Jezusem Chrystusem Jego umiłowanym Synem"54.

The third decree of God is by which he resolved to administer (beleyden) the means necessary for repentance and belief, sufficient and efficient; which administration (beleydinghe) happens according to God's wisdom, by which he knows what is proper to his mercy and severity, and according to his righteousness, by which he is prepared (bereyt) to follow what his wisdom prescribes and to perform it.

Here follows the fourth decree, in order to save and to damn certain particular (sekere bysondere) persons; which decree depends on (steunt op) the foreknowledge of God, by which he has known from eternity which persons - according to such administration of the means proper for repentance and faith - through his prevenient grace would (souden) believe, and through subsequent grace would persevere, and also which would not believe and not persevere”. J. Arminius, Declaration, w: Works, t. 1, s. 653-654, cyt. w: K.D. Stanglin, dz. cyt., s. 86-87.

50 Por. R.E. Olson, Arminian Theology, s. 184.

${ }^{51}$ Por. tenże, Historia teologii, s. 502.

52 Por. W.S. Gunter, dz. cyt., s. 180-181; R.E. Olson, Arminian Theology, s. 184.

${ }_{53}$ Por. R.E. Picirilli, dz. cyt., s. 49-50; K.D. Stanglin, Th.H. McCall, dz. cyt., s. $138-139$.

54 „We place Christ as the foundation of this predestination... For the love with 
Liczba wybranych w Chrystusie jest więc nieokreślona. Nie ma mowy o ograniczonej grupie zbawionych ludzi ${ }^{55}$, ponieważ Boża elekcja opiera się na wszechwiedzy Boga. Stwórca od zawsze wiedział, jak na jego zbawienną ofertę zareaguje każda ludzka istota ${ }^{56}$. W skrócie można powiedzieć, że idea predestynacji Arminiusza dotyczy zbawienia przez Chrystusa, a nie przez Boży wybór.

Niektórzy teolodzy reformowani uważali, że profesor z Leiden właściwie doprowadził do tego, że to człowiek wybiera Boga, a nie odwrotnie. Jednak nie jest to prawdą, gdyż wiara będąc warunkiem wybrania sprawia, że jedyną przyczyną elekcji jest Bóg. Mianowicie, Stwórca odpowiedział na upadek ludzkości ustanowieniem swego Syna Odkupicielem pokutujących i wierzących w Niego. On w Nim wybrał zbawionych! Zatem wszyscy wierzący w Chrystusa są wybrani. Bóg również wybrał tych, którzy odrzucili Zbawiciela, jako potępionych. Jest to więc zbiorowa nieokreślona elekcja i zatracenie. Następnie Stwórca przeznaczył do zbawienia te konkretne osoby, o których wiedział, że przez wiarę znajdą się w Chrystusie, oraz potępił te indywidua, które zgodnie z jego wszechwiedzą odrzucą Jego Syna ${ }^{57}$. Główną różnicą predestynacji arminiańskiej od kalwińskiej nauki o Bożej elekcji jest jak zauważa William G. Witt: „[...] wybranie tych, którzy mają wiarę w Chrystusa [...] w którym nikt nie znajduje się bez wiary" 58 .

which God loves people absolutely for salvation, and according to which he absolutely intends to give them eternal life, does not exist except in Jesus Christ his dear Son". J. Arminius, Disputationes privatae, de plerisque Christianae religionis capitibus, incoatae potissimum ab auctore ad corporis theologici informationem, XL.4, cyt. w: K.D. Stanglin, Th.H. McCall, dz. cyt., s. 139.

${ }^{55}$ W tym sensie, że jedynie wąska część ludzi ma szanse na zbawienie.

56 Por. R.E. Olson, Arminian Theology, s. 184; K.D. Stanglin, dz. cyt., s. 84.

57 Por. R.E. Olson, Arminian Theology, s. 184-185; K.D. Stanglin, Th.H. McCall, dz. cyt., s. 134-137.

${ }^{58}$ Dla porównania podaję cała wypowiedź: „Election and predestination are not the unconditional and mysterious choosing of certain individuals known only to God, but is rather the election and predestination of those who $\mathrm{h}$ ave $\mathrm{faith}$ in $\mathrm{Chr}$ is t their redeemer. Election is in Christ, but $\mathrm{no}$ o ne is in Christ with out f a it h". W.G. Witt, Creation, Redemption and Grace in the Theology of Jacob Arminius, (dysertacja doktorska) Uniwersytet Notre Dame 1993, s. 705. 


\section{ZAKOŃCZENIE}

Podsumowując niniejszy artykuł, można powiedzieć, że postreformacyjny teolog z Holandii był bardziej niezrozumiany niż jakikolwiek inny protestancki uczony. Dlatego też strona reformowana oceniła go fałszywie! Po przeanalizowaniu pism reformatora widać jasno, jak wiele opinii na temat teologii Arminiusza należy uznać za mit. Okazało się bowiem, że jego teologia nie zaprzeczała Bożej suwerenności ani totalnej deprawacji natury ludzkiej. W przypadku pierwszego tematu leideńczyka odróżniało od tradycyjnych kalwinów to, że nie popadł w determinizm, przy jednoczesnym zachowaniu radykalnej wiary w Bożą opatrzność. Uniknął przez to w swym nauczaniu implikacji o Bożym autorstwie grzechu, która jest nie do pogodzenia z Objawieniem biblijnym. Leideński profesor doprowadził również do pogodzenia dwóch prawd - suwerenności Boga i wolności człowieka (bez zbytniego wynoszenia wolnej woli ludzkiej). Przez wzgląd na negatywną antropologię i koncepcję łaski uprzedzającej nie można nazwać Arminiusza ani pelagianinem, ani humano-centrycznym teologiem. Sercem jego myśli była wiara w miłosierdzie i powszechną wolę zbawczą Boga. To wszystko nie pozostawia wątpliwości, że był on ortodoksyjnym protestantem, który nie godził się na radykalną formę kalwinizmu, wyostrzającą naukę o podwójnej predestynacji. Ten fakt nie czyni go nie-protestantem. Wcześniej najwybitniejszy współpracownik Lutra, Filip Melanchton, również nie popierał predestynacjonizmu. Można się pokusić o stwierdzenie, że teolog z Leiden był reformatorem teologii reformowanej, tworząc w jej granicach nowy nurt. Nurt ten przetrwał i stał się w protestantyzmie trzecią wielką tradycją teologiczną ${ }^{59}$, dołączając do dwóch starszych, luteranizmu i kalwinizmu, jako arminianizm.

$\mathrm{Z}$ tego powodu rodzi się pytanie, czy arminianizm jest formą kryzysu teologii reformowanej? Kalwińscy teolodzy odpowiedzieliby, że tak. Atoli należy powiedzieć, że myśl holenderskiego reformatora stała się raczej jej nową odmianą. Alternatywą zarówno dla klasycznego kalwinizmu, jak i dla jego skrajnych postaci (ekstremalny kalwinizm, hiperkalwinizm). Natomiast jeśli uznać doktrynę o Bożym bezwarunkowym

59 Warto dodać, że arminianizm nie jest systemem teologicznym podejmującym wszystkie tematy, zasadniczo ogranicza się on do soteriologii i tego, co się z nią łączy. 
wybraniu pewnej ograniczonej grupy osób do zbawienia za herezję, to reakcja Arminiusza jawi się wówczas jako przełom, porzucił on bowiem kalwiński zbawczy ekskluzywizm na rzecz ewangelicznego uniwersalizmu. Można zatem stwierdzić, że arminiański zwrot tchnął na nowo w chłodny reformowany świat ciepło Bożego nieograniczonego niczym miłosierdzia.

Streszczenie. Zadaniem artykułu jest ekspozycja postaci i myśli Jakuba Arminiusza. Autor zaczął od krótkiej biografii leideńczyka, tak by usytuować go w odpowiednim kontekście historyczno-geograficznym chrześcijańskiej Europy. Tłem zaś, mającym uwydatnić niezwykłość arminiańskiej teologii, jest kalwinizm przełomu XVI i XVII w. Autor przedstawił konflikt między Arminiuszem i kalwinistami, obejmujący odmienne spojrzenie na kluczowe fragmenty Listu św. Pawła do Rzymian (Rz 7 i 9), Bożą suwerenność, antropologię oraz soteriologię. Na końcu została przedstawiona arminiańska wersja biblijnej nauki o Bożym wybraniu, zorientowana na osobie Syna Bożego, co zasadniczo odróżniało ją od predestynacji kalwińskiej, koncentrującej się na wyrokach Bożych względem indywidualnych osób. Całość zamyka podsumowanie zawierające ocenę kontrowersji wywołanej przez leideńskiego profesora, która zapoczątkowała nową drogę w dziejach teologii reformowanej, zwanej po dziś dzień arminianizmem.

Słowa kluczowe: Jakub Arminiusz; teologia reformowana; podwójna predestynacja; arminianizm; kalwinizm.

Summary. Jacob Arminius - Reformer of the Reformed Theology. The main purpose of this paper is to present Jacob Arminius and his thought. It opens with a brief biography of Arminius to help a reader to place him in the adequate historical and geographical context of Christian Europe at the time. The background that helps to emphasize the uniqueness of Arminian Theology is Calvinism at the turn of the $16^{\text {th }}$ and $17^{\text {th }}$ centuries. The author presents the conflict found between Arminius and the Calvinists, which was based on different views on the key passages of Saint Paul's Letter to the Romans (Rom.7 and 9), i.e. the concept of God's sovereignty, anthropology, and soteriology. Afterwards he deals with the Arminian version of the biblical doctrine of God's election, focused on the person of the Son of God that essentially distinguished it from the Calvinist doctrine on predestination that emphasizes God's judgment of the individuals. This paper seeks to evaluate the controversy raised by Jacob Arminius, considered to be a new path in the history of Reformed Theology, known to this day as Arminianism.

Keywords: Jacob Arminius; Reformed Theology; double predestination; Arminianism; Calvinism. 
